\title{
Temporal variation of precipitation and flow in 16 mountainous sub-basins of the Manhuaçu River
}

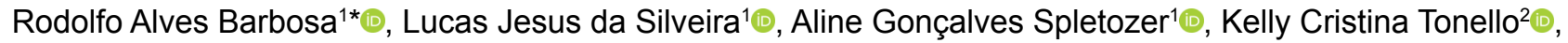 \\ João Batista Lúcio Corrêa ${ }^{3}$, Julieta Bramorski ${ }^{4} \odot$, Herly Carlos Teixeira Dias ${ }^{1} \odot$

\footnotetext{
${ }^{1}$ Universidade Federal de Viçosa, Viçosa, MG, Brasil. E-mail: rodolfo.ufv@gmail.com; ljsfloresta@hotmail.com; alinespletozer_afmt@hotmail.com; herlycarlostdias@gmail.com

${ }^{2}$ Universidade Federal de São Carlos, São Carlos, SP, Brasil. E-mail: kellytonello@yahoo.com

${ }^{3}$ Instituto Federal de Educação, Ciência e Tecnologia do Sudeste de Minas Gerais, Rio Pomba, MG, Brasil. E-mail: batistacefetrp@yahoo.com.br

${ }^{4}$ Universidade Federal do Amapá, Macapá, AP, Brasil. E-mail: bramorski@gmail.com
}

ABSTRACT: The objective of this study was to evaluate the temporal variation of precipitation and flow of several sub-basins of the Manhuaçu River-MG and to define which would need application of techniques that favor water infiltration into the soil. The study was conducted upstream the municipality of Manhuaçu, where the morphometric characterization was carried out in 23 sub-basins; land use classification through LandSat 8 OLI scenes; reference flow of 16 sub-basins was evaluated over 14 months, between May 2018 to July 2019; precipitation was measured by using four local rain gauges. The basin has cover predominance of coffee, $31.06 \%$. Among evaluated sub-basins, those with the greatest temporal variation of flow were the Córrego Fundo, Córrego Palmital, Córrego Manhuaçuzinho, and Córrego São Sebastião. The Manhuaçu River basin has a large temporal variation flow, with a marked reduction during the winter and a high elevation during the period of intense rains, requiring soil and water conservation techniques to promote the regulation of watercourses, thus reducing floods in Manhuaçu.

Key words: floods; forest hydrology; water infiltration

\section{Variação temporal da precipitação e da vazão em 16 sub-bacias montanhosas do Rio Manhuaçu}

RESUMO: O objetivo deste trabalho foi avaliar a variação temporal de precipitação e vazão de variadas sub-bacias do Rio Manhuaçu-MG e definir quais sub-bacias necessitam de aplicação de técnicas que favoreçam a infiltração de água no solo. 0 estudo foi realizado a montante da cidade de Manhuaçu, onde foi feita a caracterização morfométrica em 23 sub-bacias; classificação de uso da terra através de cenas LandSat 8 OLl; foi avaliada a vazão de referência de 16 sub-bacias por um período de 14 meses, entre maio de 2018 a julho de 2019; a precipitação foi medida em quatro pluviômetros locais. A bacia possui predominância de cobertura por café, $31,06 \%$. Dentre as sub-bacias avaliadas, as que apresentaram maior variação temporal de vazão foram o Córrego Fundo, Córrego Palmital, Córrego Manhuaçuzinho e Córrego São Sebastião. A bacia do rio Manhuaçu apresenta grande variação temporal de vazão, ocorrendo acentuada redução da vazão durante o período de inverno e grande elevação durante o período de chuvas intensas, sendo necessária a aplicação de técnicas conservacionistas de solo e água para promover regulação dos cursos d'água, reduzindo a ocorrência de enchentes em Manhuaçu.

Palavras-chave: enchentes; hidrologia florestal; infiltração de água

\footnotetext{
* Rodolfo Alves Barbosa - E-mail: rodolfo.ufv@gmail.com (Corresponding author)

Associate Editor: Ademir de Oliveira Ferreira
} 


\section{Introduction}

In recent decades, significant changes in the temporal distribution of rains have influenced water availability. This has caused prolonged droughts and floods (Avila et al., 2016), leaving the population more vulnerable to climatic factors (Lei \& Zhu, 2018).

After precipitation, the amount of water retained in the soil varies with the land cover (Lei \& Zhu, 2018), soil type (Beutler et al., 2002), vegetation development (Sun et al., 2018), adopted management practices (Mendes Junior et al., 2018), and the intensity of said precipitation (Ávila et al., 2016).

Maintaining water in the soil favors plant development and contributes to the recharge of aquifers (Silva et al., 2015). With this in mind, adopting soil and water conservation practices is fundamental to meet the water demand from the population (Gomes et al., 2012). Hence, land cover changes can alter water dynamics within the watershed, leading to soil degradation and reduced infiltration capacity (Lei \& Zhu, 2018).

Disorderly growth of cities and increased incidence of extreme precipitation events promote the occurrence of floods, thus putting the population at risk (Ávila et al., 2016). Therefore, when such extreme events happen in the contributing basin, the risk of peak flows is very high within watersheds located in mountainous regions, making the hydrological monitoring and adoption of practices that conserves water in the soil important to reduce flood risks (Silva et al., 2020; Domingues et al., 2020).

In the Manhuaçu River basin, the presence of coffee plantations and cattle production around the headwaters is traditional, making the adoption of adequate management practices essential to promote water infiltration into the soil. These soil and water conservation measures promotes infiltration, increased groundwater levels, and regulation of watercourses (Gomes et al., 2012).

Characterizing and monitoring sub-basins are fundamental for adopting more effective conservation techniques. The region of the Manhuaçu River headwaters has anthropic activities in places of great slope, which favors surface runoff and ends up promoting flooding, causing great damage and environmental impacts. Therefore, prioritizing the adoption of soil and water conservation measures in sub-basins is necessary for better management of water resources. This study aimed to evaluate the water dynamics in sub-basins of the Manhuaçu River-MG, as well as to define the need for technical intervention for improving water infiltration into the soil.

\section{Materials and Methods}

\section{Study area description}

The Manhuaçu River basin is located in the central eastern portion of the Rio Doce basin, bordering the state of Espírito Santo. The evaluated site was limited to the mouth

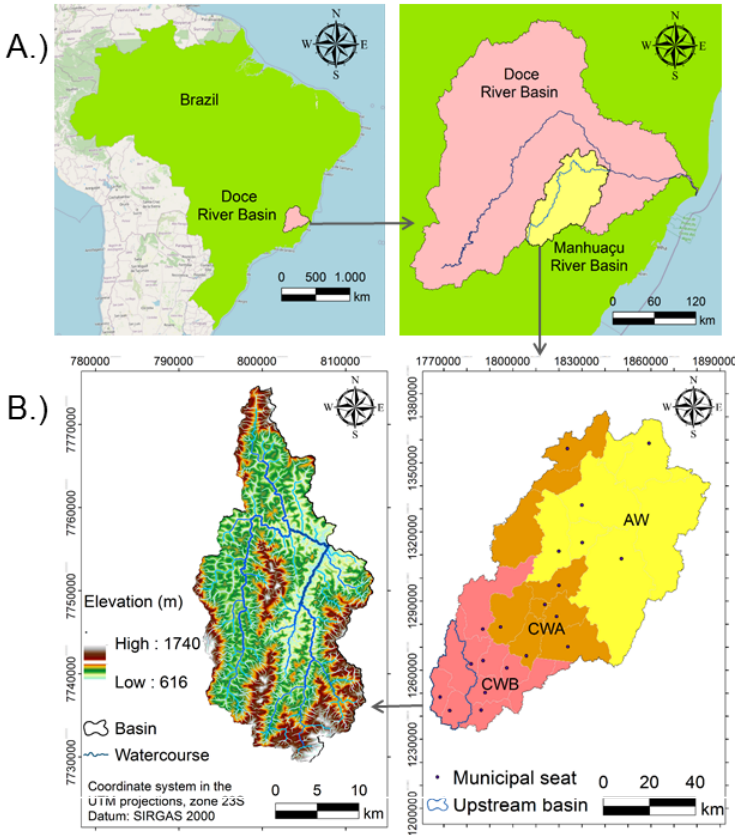

Figure 1. Study area location in the Manhaçu River basin, MG (A.), hypsometry of the basin (B.)

upstream the municipality of Manhuaçu, fully covering the municipalities of São João do Manhuaçu and Luisburgo and partially Manhuaçu, with $41.61 \%$ of its territory inserted into the area considered by the study (Figure 1). Characterized by having many rural properties, this region presents the climate classified as Cwb, according to the Köppen classification, having a humid temperate climate with dry winters and temperate summers.

\section{Data processing}

A database of contour lines, quoted points (http://iede.fjp. mg.gov.br/) and mapped hydrography (http://www.ibge.gov. $\mathrm{br} /$ ), both at the 1:50,000 scale, were used in delimiting the Manhuaçu River basin. Data were reprojected and used for the generation of a Hydrologically Consistent Digital Elevation Model (HCDEM), which is a model characterized by having a sharp coincidence between the numerical hydrography (raster) with the mapped one (vector).

Several corrections and adjustments to the hydrography were needed in order to generate the HCDEM, as the Topo to Raster interpolator, necessary to make the hydrography unifilar, requires them. Double-banked streams were replaced by the centerline, polygons such as lakes and dams were identified by the Geometric Network tool and corrected by the editing tool; connected, through the geometric network, where disconnected locations are identified and corrected by the editing tool; and oriented, where each hydrography segment should be oriented towards the mouth. After generating the model, possible anomalies are corrected to ensure that water will flow from higher to lower locations.

A systematic and organized method is required to obtain accurate results to generate the hydrograph. For this, the flow direction and cumulative flow in each cell indicate where 
the channel areas have been established; therefore, the tool indicates the location of main channels. This method has an output that is the basis for creating flow-order vectors, corresponding to the river hierarchy as according to the number of the Strahler stream order (1964). Data processing and analyses were performed in a Geographic Information System (GIS) environment, ArcGIS 10.2.2 software.

After delimiting the basin and drainage network, 16 subbasins were selected for flow monitoring and environmental characterization. They were chosen because of their easy access for monitoring and for being representative for the study.

\section{Image classification}

Supervised classification of the images was by using the Maximum Likelihood algorithm (maxver) employed through the ArcGis 10.2.2 software interface. This procedure uses the mean and covariance of training samples to compute the statistical probability of an unknown pixel taking part of a given class, which is assigned to the category of highest probability after the probabilistic evaluation.

LandSat $8 \mathrm{OLI}$ scenes with 30 meters of spatial resolution from January 20, 2018, passing date of the sensor, were acquired and subsequently processed and sampled for training to perform supervised classification by using the Maximum Likelihood classifier (maxver).

Selection of land cover classes was deemed as the predominant field observations in the basin, with five main classes considered, namely: native forest; coffee; pasture; eucalyptus; and urban occupation. The efficiency of both classification and validation was evaluated by the overall accuracy index and the kappa.

\section{Precipitation collection}

Precipitation was evaluated for 14 months, with two rain gauges installed in the basin region; one in the municipality of Simonésia, in January 2018, and another in the municipality of Manhuaçu, Ponte do Silva district, in March 2018. These rain gauges had aperture of $172 \mathrm{~cm}^{2}$ and the measurement was with a graduated cylinder.

Data from a station located in São João do Manhuaçu, owned by the Companhia de Saneamento de Minas Gerais (COPASA), was also employed as well as data from the automatic station located in the municipality of Manhuaçu, which also provides data for the National Institute of Meteorology (INMET).

After collection, data were tabulated and interpolated to evaluate the precipitation variation in the basin and the Thiessen Method was used to determine areas of influence of the rain gauges. This method generates a weighted average of the heights recorded by the rain gauges, which is directly proportional to the basin area of influence, it also considers the non-uniformity of spatial distribution of the stations, and does not take into account the basin relief (Marciano et al., 2019). To delimit these areas, the Thiessen Poligon tool of
ArcGIS software was employed. The area of influence has a weight in relation to the total area, expressed by Equation 1.

$$
\mathrm{Fp}=\frac{\mathrm{Ai}}{\mathrm{A}}
$$

where: $\mathrm{Fp}=$ Weighting Factor; $\mathrm{Ai}=$ Area of influence of the rain gauge within the basin; $A=$ basin total area.

Mean precipitation of the basin by the Thiessen method was obtained according to Equation 2.

$$
\operatorname{Pt}(\mathrm{mm})=\frac{\sum \mathrm{Pi} \times \mathrm{Ai}}{\mathrm{A}}
$$

where: $\mathrm{Pt}=$ Mean precipitation by the Thiessen method; $\mathrm{Pi}=$ precipitation registered in the rain gauge; $\mathrm{Ai}=$ Area of influence of the rain gauge within the basin; $A=$ basin total area.

Besides the stations, historical data from rain gauges located near the basin, in Alto Jequitibá and Martins Soares, were used as reference for the site.

\section{Reference flow record}

Reference flow rate from 16 sub-basins was evaluated and monitored for a 14-months period, between May 2018 and July 2019. During this period, six visits were paid to the sub-basins: May 2018; November 2018; January 2019; March 2019; May 2019; and July 2019. The reference flow rate was measured by the micro-vane method, where instrument counts the number of spins of its propeller for a given time and then calculates the speed instantaneously, which is in turn recorded by the operator. To find the flow it is necessary measuring the area of the river section, for which a tape measure was used and, after finding the area, it is multiplied by the velocity to obtain the approximate flow rate obtain (Equation 3).

$$
\mathrm{Vr}=\mathrm{L} \times \mathrm{h} \times \mathrm{V}
$$

where: $V r=$ reference flow rate, $\mathrm{m}^{3} \mathrm{~s}^{-1} ; \mathrm{L}=$ channel width in $\mathrm{m}$; $\mathrm{h}=$ mean depth of the channel section in $\mathrm{m} ; \mathrm{v}=$ mean water flow velocity $(\mathrm{m} / \mathrm{s})$;

\section{Defining the conservation techniques}

Information collected on land use and cover, flow and field trips enabled to evaluate the sub-basins with the greatest temporal variation of flow and flood risk. Based on this very information, suggesting conservation techniques aimed at proper management was then made possible.

\section{Results and Discussion}

Water dynamics (flow) in sub-basins of the Manhuaçu River-MG

The upstream basin of the Manhuaçu River has 89 subbasins, with 45 of these of first order; 21 of second order; 
Table 1. Characteristics of monitored sub-basins in the watershed from Manhuaçu River-MG.

\begin{tabular}{|c|c|c|c|c|c|c|}
\hline Sub-basin & Main water course & $\begin{array}{l}\text { Area } \\
\left(\mathrm{km}^{2}\right)\end{array}$ & $\begin{array}{c}\text { Perimeter } \\
(\mathrm{km})\end{array}$ & $\begin{array}{c}\text { Minimum elevation } \\
\qquad(\mathrm{m})\end{array}$ & $\begin{array}{c}\text { Maximum elevation } \\
\text { (m) }\end{array}$ & $\begin{array}{l}\text { Canal } \\
\text { order }\end{array}$ \\
\hline 1 & C. Paraíso & 3.64 & 8.00 & 830.61 & $1,234.78$ & $3^{\text {rd }}$ \\
\hline 2 & C. São Benedito & 3.55 & 9.68 & 828.95 & $1,526.96$ & $2^{\text {nd }}$ \\
\hline 4 & C. Fundo & 3.45 & 8.95 & 817.00 & $1,611.41$ & $3^{\text {rd }}$ \\
\hline 5 & C. São Bento & 2.44 & 6.53 & 808.50 & $1,116.10$ & $2^{\text {nd }}$ \\
\hline 6 & C. Caratinga & 7.59 & 12.81 & 792.33 & $1,580.38$ & $4^{\text {th }}$ \\
\hline 8 & C. Rubens & 1.60 & 5.49 & 767.15 & $1,018.81$ & $2^{\text {nd }}$ \\
\hline 9 & C. Cachoeira & 0.56 & 3.32 & 738.74 & $1,062.12$ & $1^{\text {st }}$ \\
\hline 10 & C. Cachoeira Chata & 0.99 & 4.50 & 736.31 & $1,079.31$ & $2^{\text {nd }}$ \\
\hline 11 & C. Palmital & 5.85 & 11.52 & 691.60 & $1,498.27$ & $3^{\text {rd }}$ \\
\hline 12 & C. Taquara Preta & 12.73 & 20.16 & 677.76 & $1,587.67$ & $3^{\text {rd }}$ \\
\hline 13 & C. Manhuaçuzinho & 64.63 & 49.61 & 673.43 & $1,628.50$ & $5^{\text {th }}$ \\
\hline
\end{tabular}

16 of third order; 5 of fourth order; 1 of fifth order and 1 of sixth order (Figure 2A, Table 1). The 16 sub-basins that went under reference monitoring had an area varying from 0.56 to $242.93 \mathrm{~km}^{2}$ and corresponded to $74 \%$ of the Manhuaçu River drainage area.

The amplitude between the maximum and minimum elevations found in the 16 sub-basins were high, suggesting predominance of a mountainous relief in the Manhuaçu River basin (Table 1, Figure 2B). This characteristic results in a reduced concentration time (Domingues et al., 2020), making the municipality susceptible to a great variation in the river water volume, which can cause flooding during the rainy season, harming the population that live near the river and the public services of the municipality.

The sub-basin of the São Luís River was the largest evaluated and the one that had greatest altimetric amplitude and predominance of a mountainous relief (Table 1, Figure 2B). Most of this basin area is related to the main channel higher order, which potentiates

A.

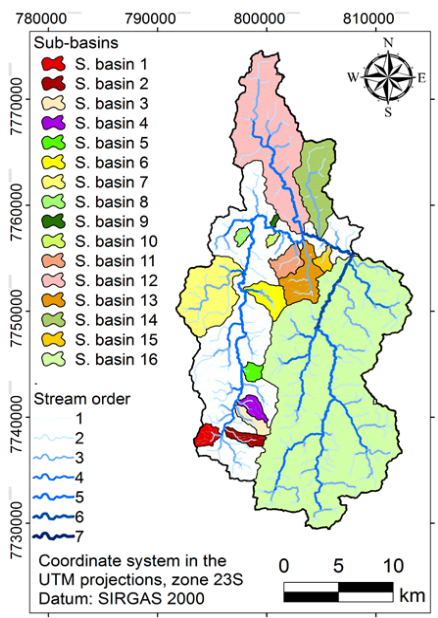

B.

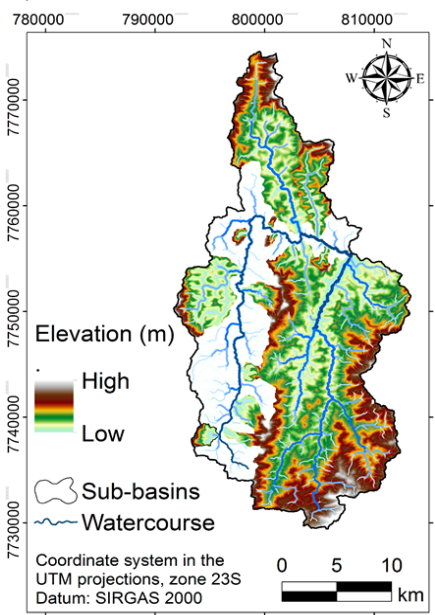

Figure 2. Hydrography of the Manhuaçu River basin and division of its 16 sub-basins (A.); hypsometry of evaluated sub-basins in the Manhaçu River-MG (B.). greater water production due to the equally greater cloud overlapping possibility and the rain spatial distribution over it (Dikpal et al., 2017).

Land use classification had an global accuracy index of 0.80 and a Kappa index of 0.75 . Coffee plantations, with $31.06 \%$, were the predominant land cover of the basin area; followed by cattle pasture, with $21.94 \%$; and eucalyptus plantations, representing $17.87 \%$. On the other hand, native vegetation represented $27.03 \%$ of the area, with greater presence in springs and hilltops, being little evident in the riparian zone along the watercourses (Figure 3A).

There is a predominant rainy period in the basin between the months of October and March, corresponding to $80 \%$ of the total precipitation of the historical average. During it, the precipitation varied among stations, with this variation observed also in the flow of the sub-basins. January had precipitation below average for the site and. between November 2018 and January 2019, a reduced flow was observed. The highest precipitation was in São João do Manhuaçu (1,365 mm) between May 2018 and July 2019 (Figure 3B). Average precipitation by Thiessen Polygon was of $1,095 \mathrm{~mm}$ for the monitoring period of the basin between May 2018 and July 2019 (14 months), below the common precipitation for Manhuaçu-MG, 1,319 $\mathrm{mm}_{\text {year }}{ }^{-1}$ (Alvares et al., 2013).

Employed by several authors (Macêdo et al., 2013; Marciano et al., 2019), Thiessen polygon method allows using rain gauges located within and near basins for estimating mean precipitation. Macêdo et al (2013) evaluated the factors that influence the hydrological behavior in a western Amazonia sub-basin and verified differences of $32 \mathrm{~mm}$ in the values found for precipitation when comparing the methods of arithmetic mean and by Thiessen polygon.

An Indian summer (known as "veranico") took place in January in the Manhuaçu River basin. This river belongs to the Rio Doce basin, which has a precipitation pattern of a longer 
A.
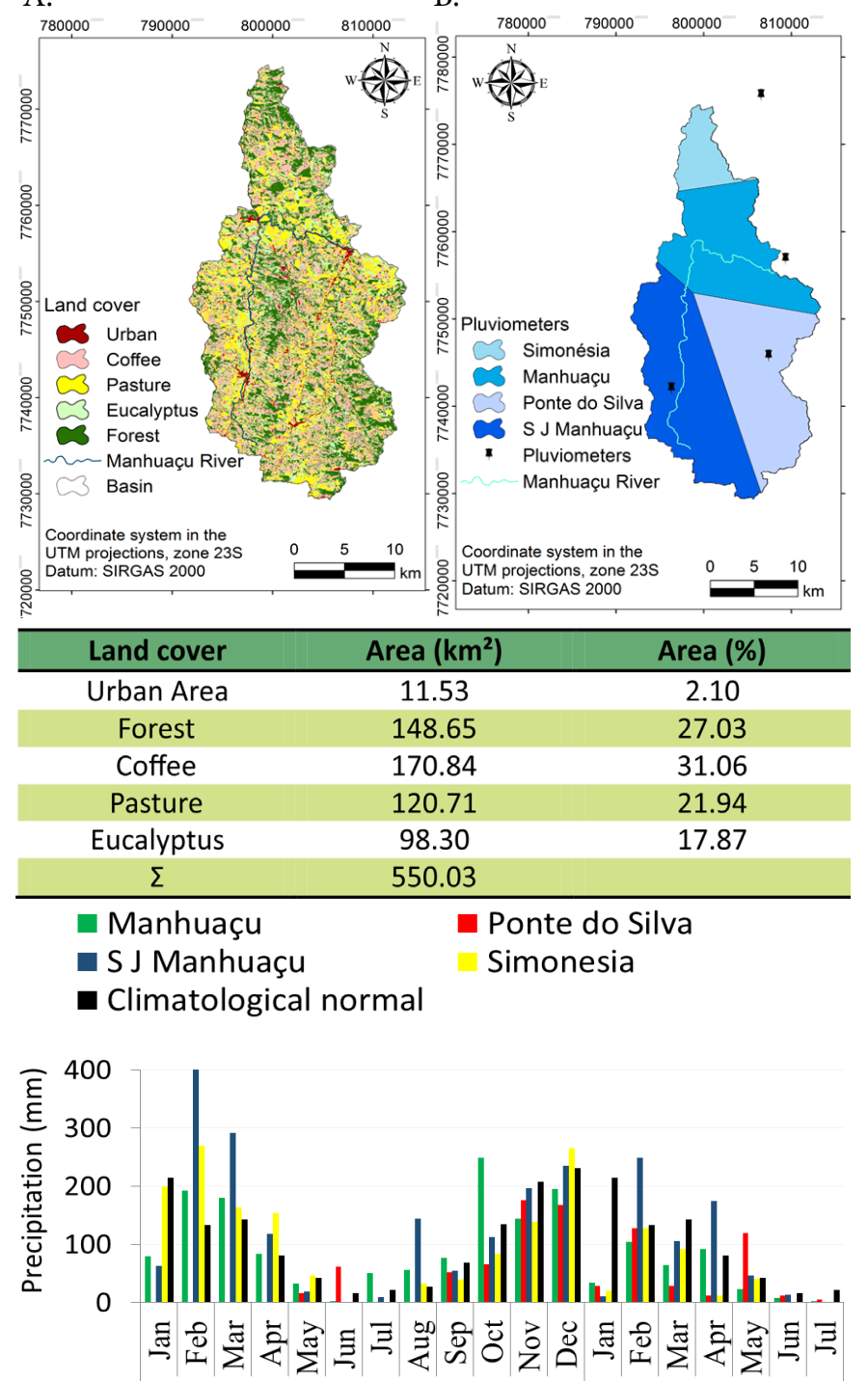

2018

Months

2019

Figure 3. Classes of cover and land use (A.) and total precipitation recorded with pluviometers between May 2018 and June 2019, and area reached by the Thiessen Polygon method (B.) in the watershed from Manhuaçu River-MG.

rainy period in its western region and longer dry seasons in its eastern region, as well as interruption in precipitation during summer, the "veranico", which is greater towards the coastal region (Cupolillo et al., 2008).
In the Córrego Manhuaçuzinho basin, a higher flow rate was observed in January when compared to November. Moreover, in the months prior to March, a high precipitation was recorded by the rain gauge located in Simonésia, which may have contributed to the supplying of the aquifers (Figure 4A). The highest flow observed was in the São Luís River $(3,603$ $\left(\mathrm{s}^{-1}\right)$, in November 2018 (Figura 4b).

Córrego Cachoeira and Córrego Cachoeira Chata subbasins showed higher reference flow in November 2018, different from the ones closer to the seat of the municipality, with higher flow in March of the same year (Figure 5). These sub-basins are also considered as micro drainage basins with first and second order channels, respectively, where they are also considered fragile areas that are threatened by disturbances with greater frequency (Calijuri \& Bubel, 2006).

The Córrego Palmital sub-basin had a sharp reduction in the measured flow during the evaluated period. Growing urban occupations and fragmentation of rural properties increase the soil sealing, thus, in turn, favoring a peak flow (Figure 5).

Córrego Fundo presented a peak flow in May 2018, with the basin shape, occupation and present soil class having contributed to the flow variation. This flow variation was more pronounced in the sub-basins of Córrego Manhuaçuzinho, Córrego dos Faustinos, Córrego Fundo, Córrego Palmital, and Córrego São Sebastião (Figure 6).

Precipitation characteristics interfere in water erosion; the intensity, frequency, duration and erosivity are mainly responsible for disaggregating and dragging the particles (Santos et al., 2010). Córrego Fundo demonstrated a high flow rate in May, compared to the other collections; most of the basin is anthropized due to the proximity to the municipality and has great variation in elevation, which can in turn accentuate flow variation.

There is a high correlation ( 0.60 ) between heavy rains and flooding, concerning the mountainous region of Rio de Janeiro (Ávila et al., 2016). Silva et al. (2020) reported that the South Atlantic convergence zone and passage of a frontal system were responsible for $80 \%$ of precipitation and $20 \%$ were related to local convective storms in the Quitandinha river basin. They also stated that $85 \%$ of precipitation occurred near the mountainous region of Rio de Janeiro, characterizing the importance of topography in formation of rains in this
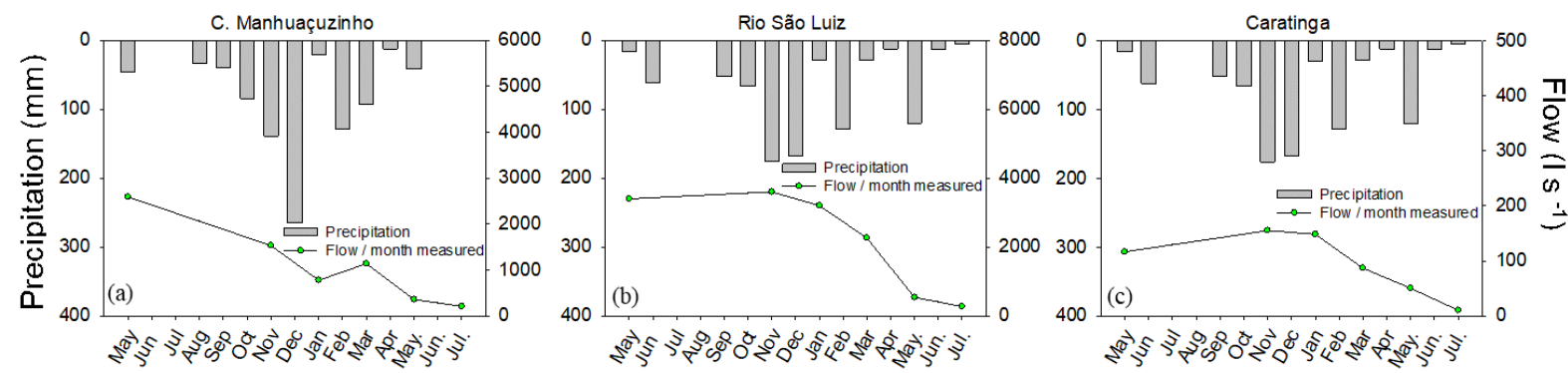

Months

Figure 4. Precipitation hydrograph and reference flow rate of sites under influence of the rain gauge 1 in Simonésia (a) and 3 in Ponte do Silva (b,c), in the drainage basin of the Manhuaçu River-MG between May 2018 and June 2019. 

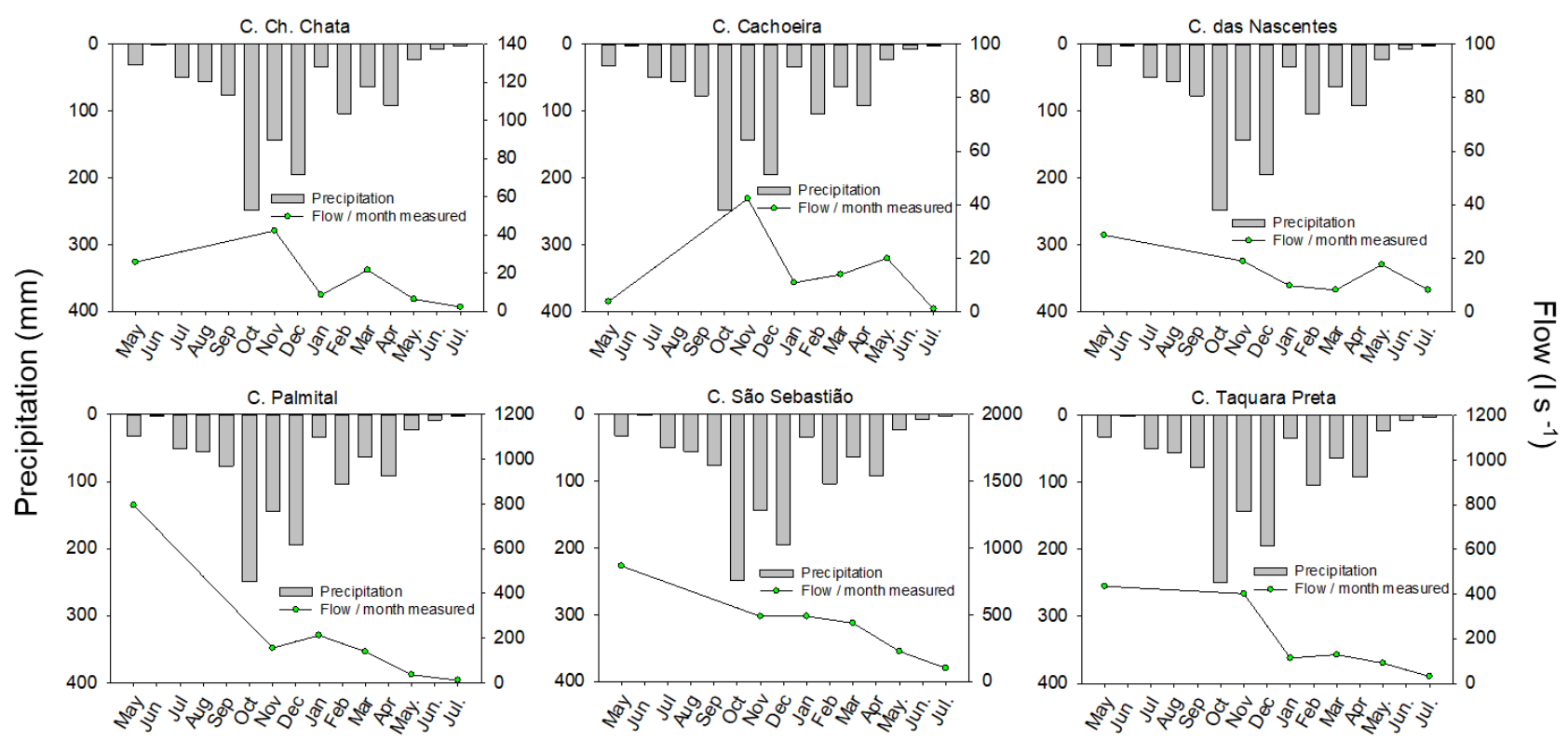

Months

Figure 5. Precipitation hydrograph and reference flow rate of sites under influence of the rain gauge 2, in Manhuaçu in the Manhuaçu River-MG drainage basin between May 2018 and July 2019.
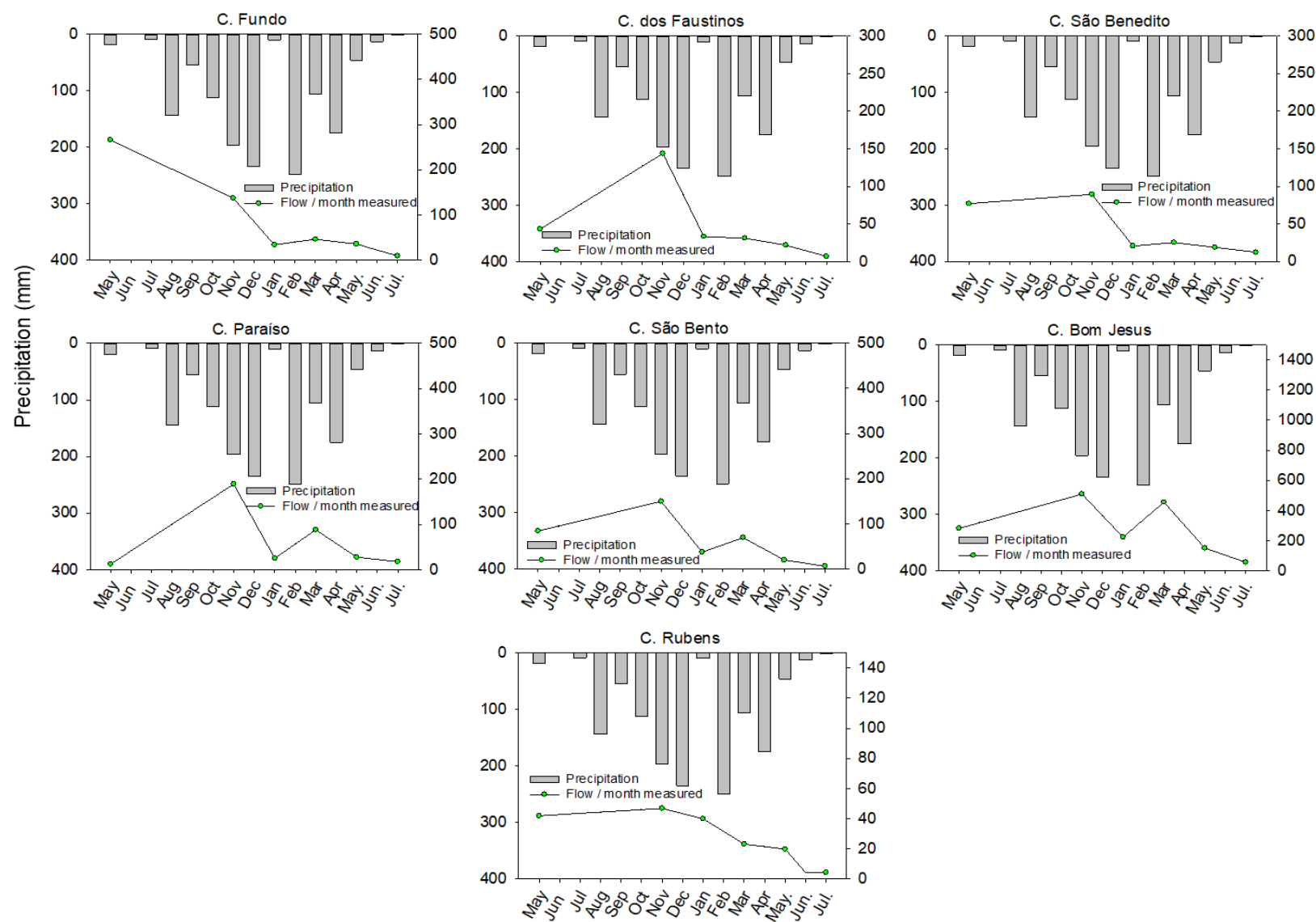

Months

Figure 6. Precipitation hydrograph and reference flow rate of sites under influence of the rain gauge 4, in São João do Manhuaçu in the Manhuaçu River-MG drainage basin between May 2018 and July 2019.

region. Domingues et al. (2020) evaluated the flood risk in the Pardo River basin due to the high slope and high maximum flow by the permanence curve $\left(108.06 \mathrm{~m}^{3} \mathrm{~s}^{-1}\right)$, paying special attention to the proximity to the Serra do Caparaó.
Soil conservation techniques that favor water infiltration into the soil

Implementing conservation techniques for coffee production allows greater infiltration of water into the soil in 
the Manhuaçu River basin. Techniques involving weeding the coffee rows and planting downhill favor erosion and surface runoff, and are currently adopted by only few landowners in the region. Coffee produced while adopting conservation practices allows a significant reduction in the loss of water, soil and $\mathrm{N}$ in relation to the conventional system; furthermore, keeping the soil covered with vegetation contributes to the reduction of losses (Guimarães et al., 2015).

Adopting vegetative practices such as the maintenance of vegetation on the coffee tree paths favors soil moisture retention (Castanheira, 2018). Mechanical practices, such as micro-tillage and water retention basins, are recommended for mountainous regions (Alves et al., 2017). Mendes Júnior et al. (2018) verified high soil loss potential with the absence of soil and water conservation practices for coffee, maize, and bean crops in the Córrego da Laje basin, in Alfenas-MG.

Among evaluated sub-basins, some presented greater flow variation, having less watercourse regularity. Córrego Manhuaçuzinho and Córrego São Sebastião are where coffee crops and pastures are predominant and most of the properties adopt conservation techniques; yet, the great slope and presence of shallow soils ended up in a greater loss of water from the sub-basins. However, adopting conservation techniques can lead to greater infiltration of water into the soil and improve the flow regulation, with the application of mechanical techniques for conserving the rural raods being also recommended.

Observed pastures demonstrated laminar erosion and productivity loss in evaluated sub-basins, representing a greater risk of surface runoff of the rainwater in these locations. Animal husbandry is an economic activity in the region, practiced by producers who trade milk and other dairy products through local cooperatives. Silva (2013) recorded a $5 \%$ increase in dairy cattle production between 2002 and 2010 in the micro-region of Manhuaçu, conditioned to the increase in the number of animals, from 24,890 to 37,808 milking cows, having no increase in pasture productivity.

Eucalyptus production is characterized as the main existing forest plantation in the region, with the wood produced used for maintenance of rural property, fence building, coffee drying, charcoal production, and civil construction; part of the plantations observed was densified, increasing competition for growth resources such as water and nutrients. Sun et al. (2018) observed higher soil moisture-holding capacity under eucalyptus plantation when compared to other crops for 5 years, also verifying that sediment loss and surface runoff was lower in more mature plantations, favoring soil water infiltration.

The sub-basins Córrego Fundo, Córregos dos Faustinos and Córrego Palmital have a greater urban occupation presence, thus presenting a larger impermeable area, which reduces the water infiltration into the soil and sharply increasing the flow in these basins, thus requiring conservation practices on rural roads, and the adequacy of lots and forest restoration, especially in the riparian zone.

Many areas with condominiums and small farms were located, thus requiring the removal of land and landfill in places close to the watercourses, causing their silting and degradation. Opening condominiums requires soil disturbance for clearing lots and the adequacy of streets, such practices with negative environmental impacts, due to the lack of greater efficiency in the authorization and supervision of this venture type (Barbosa et al., 2018). Urban growth occurs in a disorganized manner, especially in the municipality of Manhuaçu, where constructions on the banks from the Manhuaçu River cause environmental impacts such as the discharge of effluents and silting (Oliveira et al. 2019).

Adopting conservation techniques is essential for regulating basin flow. Techniques that are suggested for sub-basins are relative to similar characteristics of seasonal variation, land use, and physical characteristics (Table 2). Damping the impact of raindrops on the soil, responsible for the triggering of the erosive process, is fundamental, where forest restoration, coffee plantations management, adoption of intercropping systems and productive maintenance of pastures are vegetative techniques that favor the infiltration processes (Guimarães et al., 2015). Gomes et al. (2012) observed that after implementation of techniques of management and soil conservation in the basin of Ribeirão São Bartolomeu, the minimum flow increased from $80 \mathrm{I} \mathrm{min}^{-1}$, in 2002 , to $188 \mathrm{I} \mathrm{min}^{-1}$, in 2004, thus proving the efficiency of using techniques for water conservation in the soil.

Application of forest restoration techniques is recommended for the riparian zones of the basins, since they have great variation in humidity and the permanence of native forest favors the water quality in the basin (Pires et al., 2017). The Córrego Cachoeira Chata sub-basin was the one with the highest cover of native forest in the contribution basin, having greater flow regulation.

Table 2. Conservation techniques suggested for sub-basins of Manhuaçu River, MG.

\begin{tabular}{|c|c|}
\hline Sub-basins & Suggested techniques \\
\hline $\begin{array}{l}\text { C. Manhuaçuzinho, C. São } \\
\text { Sebastião, R. São Luís }\end{array}$ & $\begin{array}{l}\text { Adequacy of rural roads, conservation techniques on coffee plantations (inter-row covering, } \\
\text { level planting, permanent tillage, micro-tillage and rainwater catchment boxes). }\end{array}$ \\
\hline $\begin{array}{l}\text { C. Fundos, C. Faustinos, } \\
\text { C. Palmital }\end{array}$ & $\begin{array}{l}\text { Adequacy of farmland and plots, micro-terracing, rainwater catchment boxes on rural roads, } \\
\text { forest restoration. }\end{array}$ \\
\hline $\begin{array}{l}\text { C. Caratinga, C. Taquara Preta, } \\
\text { C. das Nascentes, C. São Benedito }\end{array}$ & $\begin{array}{l}\text { Forest restoration of riparian areas, micro-terracing, } \\
\text { rainwater catchment boxes on rural roads. }\end{array}$ \\
\hline
\end{tabular}




\section{Conclusions}

The sub-basins had great variation in terms of temporal distribution of the rains, influencing the observed reference flow rate.

São Luís River sub-basin had the highest flow during the evaluated period among all monitored 16 sub-basins.

Coffee plantations are the main land cover, bringing about the need to produce while employing conservation techniques that favor water infiltration into the soil.

The sub-basins Corrego dos Faustinos, Corrego Fundo, Corrego Palmital, Corrego Manhuaçuzinho and Corrego São Sebastião all presented large flow temporal variation during the observed period, being recommended the improvement of water conservation techniques to provide greater flow regulation in these basins, thus reducing the flooding risk in the municipality.

Main conservation techniques recommended for the Manhuaçu river basin were the adequacy of rural roads, coffee plantations, and of farmland and plots, as well as the micro landscaping, rainwater catchment boxes, pasture recovery, and forest restoration.

\section{Acknowledgements}

The authors would like to thank the Federal University of Viçosa, FAPEMIG, Capes, CNPq and the Committee of the Bacia Hidrográfica Waters of Rio Manhuaçu River.

\section{Compliance with Ethical Standards}

Author contributions: Conceptualization: $\mathrm{RAB}$ and HCTD; Data curation: RAB, AGS, LJS, KCT, JBLC, JB and HCTD; Formal analysis: AGS, LJS, HCTD; Funding acquisition: HCTD; Investigation: RAB and HCTD; Methodology: RAB and HCTD; Project administration: HCTD; Resources: RAB and HCTD; Supervision: HCTD; Validation: RAB, AGS, LJS, KCT, JBLC, JB and HCTD; Visualization: RAB, AGS, LJS, KCT, JBLC, JB and HCTD; Writing - original draft: RAB; Writing - review \& editing: RAB, AGS, LJS, KCT, JBLC, JB and HCTD.

Conflict of Interest: There is no conflict of interest.

Funding: Coordenação de Aperfeiçoamento de Pessoal de Nível Superior - Brasil (CAPES) - Finance Code 001.

\section{Literature Cited}

Alvares, C. A.; Stape, J. L.; Sentelhas, P. C.; Gonçalves, J. L. M.; Sparover, G. Köppen's climate classification map for Brazil. Meteorologische Zeitschrift, v.22, n.6, p.711-728, 2013. https:// doi.org/10.1127/0941-2948/2013/0507.

Alves, E. L.; Pereira, F. A. C.; Dalchiavon, F. C. Potencial econômico da utilização de micro-terraceamento em lavouras de café: um estudo de caso. Revista iPecege, v.3, n.1, p.24-38, 2017. https:// doi.org/10.22167/r.ipecege.2017.1.24.

Ávila, A.; Justino, F.; Wilson, A.; Bromwich, D.; Amorim, M. Recent precipitation trends, flash floods and landslides in southern Brazil. Environmental Research Letters, v.11, n.11, e114029, 2016. https://doi.org/10.1088/1748-9326/11/11/114029.
Barbosa, S. G.; Spletozer, A. G.; Barbosa, R. A.; Silveira, L. S.; Dias, H. C. T. Impactos ambientais causados pela abertura de condomínios: Um estudo de caso no condomínio Vivendas Santa Mônica. Revista Brasileira de Gestão e Engenharia, v.2, n.18, p.159-178, 2018. http://www.periodicos.cesg.edu.br/index.php/gestaoeengenharia/ article/download/428/578. 12 Mar. 2020.

Beutler, A. N.; Centurion, J. F.; Souza, Z. M.; Andrioli, I.; Roque, C. G. Retenção de água em dois tipos de latossolos sob difentes usos. Revista Brasileira de Ciência do Solo, v.26, n.3, p.829-834, 2002. https://doi.org/10.1590/S0100-06832002000300029.

Calijuri, M. C.; Bubel, A. P. M. Conceituação de Microbacias. In: Lima, W.P.; Zakia, M.J.B. (Eds.). As florestas plantadas e a água. São Carlos: RiMa, 2006. p.45-60.

Castanheira, D. T. Técnicas agronômicas para mitigação dos efeitos da restrição hídrica no cafeeiro. Universidade Federal de Lavras, 2018. 125p. Doctoral Thesis. http://repositorio.ufla.br/handle/1/29016. 29 Mar. 2020.

Cupolillo, F.; Abreu, M. L.; Vianello, R. L. Climatologia da Bacia do Rio Doce e sua relação com a topografia local. Geografias, v.4, n.1, p.4560, 2008. https://periodicos.ufmg.br/index.php/geografias/article/ download/13251/10483. 19 Mar. 2020.

Dikpal, R. L.; Prasad, T. J. R.; Satish, K. Evaluation of morphometric parameters derived from Cartosat-1 DEM using remote sensing and GIS techniques for Budigere Amanikere watershed, Dakshina Pinakini Basin, Karnataka, India. Apllied Water Science, v.7, n.8, p.4399-4414, 2017. https://doi.org/10.1007/s13201-017-0585-6.

Domingues, F. G.; Barbosa, R. A.; Corrêa, C. C. S. A.; Guimarães, C. M.; Silveira, L. J.; Dias, H. C. T. Caracterização morfométrica e comportamento hidrológico da bacia hidrográfica do Rio Pardo. Revista Ifes Ciência, v.6, n.2, p.3-16, 2020. https://ojs.ifes.edu.br/ index.php/ric/article/view/502. 01 Jun. 2020.

Gomes, M. A.; Lani, J. L.; Costa, L. M.; Pontes, L. M.; Figueiredo, N. A.; Bardales, N. G. Solos, manejo e aspectos hidrológicos na bacia hidrográfica do Araújos, Viçosa - MG. Revista Árvore, v.36, n.1, p.93102, 2012. https://doi.org/10.1590/\$0100-67622012000100011.

Guimarães, G. P., Andrade, K. C., Mendonça. Erosão hídrica e compartimentos de matéria orgânica do solo em sistemas cafeeiros conservacionistas e convencionais. Coffee Science, v.10, n.3, p.365374, 2015. http://www.sbicafe.ufv.br/handle/123456789/8138. 12 Apr. 2020.

Lei, C.; Zhu, L. Spatio-temporal variability of land use/lad cover change (LULCC) within the Huron River: Effects on strem flows. Climate Risk Management, v.19, p.35-47, 2018. https://doi.org/10.1016/j. crm.2017.09.002.

Macêdo, M. N. C.; Dias, H. C. T.; Coelho, F. M. G.; Araújo, E. A.; Souza, M. L. H.; Silva, E. Precipitação pluviométrica e vazão da bacia hidrográfica do Riozinho do Rôla, Amazônia Ocidental. Revista Ambiente \& Água, v. 8, n. 1, p. 206-221, 2013. https://doi.org/10.4136/ambi-agua.809.

Marciano, A. G.; Barbosa, A. A.; Silva, A. P. M. Cálculo da precipitação média utilizando método de Thiessen e as linhas de cumeada. Revista Ambiente \& Água, v.13, n.1, e1906, 2019. https://doi. org/10.4136/ambi-agua.1906.

Mendes Júnior, H.; Tavares, A. S.; Santos Júnior, W.R.; Silva, M. L. N.; Santos, B. R.; Mincato, R. L. Water erosion in oxisols under coffee cultivation. Revista Brasileira de Ciência do Solo. v.43, n.2, e01700932018, 2018. https://doi.org/10.1590/18069657rbcs20170093. 
Oliveira, T. E.; Graça, M. M.; Lidiane, E. Rio Manhuaçu (MG): O reflexo na cidade. Pensar Acadêmico, v.17, n.1, p.74-91, 2019. https:// doi.org/10.21576/rpa.2019v17i1.712.

Pires, A. P.; Rezende, C. L.; assad, E. D.; Loyola, R.; Scarano, F. R. Forest restoration can increase the Rio Doce watershed resilience. Perspectives in Ecology and Conservation, v. 15, n.3, p.187-193, 2017. https://doi.org/10.1016/j.pecon.2017.08.003.

Santos, G. G.; Griebeler, N. P.; Oliveira, L. F. C. Chuvas intensas relacionadas à erosão hídrica. Revista Brasileira de Engenharia Agrícola e Ambiental, v.14, n.2, p.115-123, 2010. https://doi. org/10.1590/S1415-43662010000200001.

Silva, F. P.; Rotunno Filho, O. C.; Silva, M. G.; Sampaio, R. J.; Pires, G. D.; Araújo, A. A. M. Identification of rainfall and atmospheric patterns associated with Quitandinha River flooding events in Petropolis, Rio de Janeiro (Brazil). Natural Hazards, v.103, p.37453764, 2020. https://doi.org/10.1007/s11069-020-04153-y.
Silva, M. F. Avaliação do programa de desenvolvimento da pecuária leiteira da região de Viçosa, Minas Gerais. Viçosa: Universidade Federal de Viçosa, 2013. 99p. Dissertação Mestrado. https:// www.locus.ufv.br/handle/123456789/5796. 12 Mar. 2020.

Silva, S. A., Queiroz, D. M., Ferreira, W. P. M., Corêa, P. C., Rufino, J. L. S. Mapping the potential beverage quality of coffee produced in the Zona da Mata, Minas Gerais, Brazil. Journal of the Food and Agriculture, v.96, n.9, p. 3098-3108, 2015. https://doi. org/10.1002/jsfa.7485.

Strahler, A.N. Quantitative geomorphology of drainage basin and channel networks. In: Chow, V.T. (Ed.). Handbook of applied hydrology. New York, McGraw Hill, 1964. p.4-76.

Sun, D.; Zhang, W.; Lin, Y.; Liu, Z.; Shen, W.; Zhou, L.; Rao, X.; Liu, S.; Cai, X.; He, D.; Fu, S. Soil erosion and water retention varies with plantation types and age. Forest Ecology and Management, v. 422, p.1-10, 2018. https://doi.org/10.1016/j.foreco.2018.03.048. 